\title{
A mediation effect of new public management on the relationship between intelligence, leader- ship, HR quality and performance of local government employees in Indonesia
}

\author{
Hendrawati Hamid $^{a^{*}}$, Murdifin Haming ${ }^{\mathrm{b}}$, Baharuddin Semmaila ${ }^{\mathrm{b}}$ and Jamaluddin Bijang ${ }^{\mathrm{b}}$
}

${ }^{a}$ Faculty of Political Governance, Institute of Public Administration (IPDN), South Sulawesi, Indonesia

${ }^{b}$ Faculty of Economics and Business, Universitas Muslim Indonesia, Makassar, Indonesia

\begin{tabular}{|c|c|}
\hline CH RON I C LE & A B S T RACT \\
\hline $\begin{array}{l}\text { Article history: } \\
\text { Received: October 24, } 2019 \\
\text { Received in revised format: No- } \\
\text { vember } 282019 \\
\text { Accepted: December 22, } 2019 \\
\text { Available online: } \\
\text { December 22, } 2019 \\
\text { Keywords: } \\
\text { Intelligence } \\
\text { Leadership } \\
\text { Human Resource Quality } \\
\text { NPM } \\
\text { Performance } \\
\text { Government Employee }\end{array}$ & $\begin{array}{l}\text { The emergence of New Public Management (NPM) phenomenon creates a new discourse that at- } \\
\text { tracts the attention of human resource management experts around the world, especially in Indone- } \\
\text { sia. To address this issue, this study tries to focus on how the performance of local government } \\
\text { employees is influenced by several factors; namely, intelligence, leadership, quality of human re- } \\
\text { sources, and NPM itself. The population of this study is government employees in the city of Ma- } \\
\text { kassar, Indonesia, and given the huge number, the sampling technique uses purposive sampling. } \\
\text { The amount determined referred to the variance-based (or Partial Least Square) Structural Equation } \\
\text { Analysis tool and obtained by } 100 \text { local government employees. Primary data collected through a } \\
\text { questionnaire is processed with the assistant of Smart PLS. The results show that intelligence, lead- } \\
\text { ership, and HR quality had positive and significant effects on NPM. The direct relationship also } \\
\text { indicates the significance of constructs on performance, except intelligence, which directly has no } \\
\text { significant impact on the performance of government employees. The NPM variable also signifi- } \\
\text { cantly mediates the indirect effect between variables. This research is expected to enrich the treas- } \\
\text { ury of knowledge in the field of human resource studies, and strategies for implementing the con- } \\
\text { cept of NPM in the government environment. }\end{array}$ \\
\hline
\end{tabular}

\section{Introduction}

New Public Management (NPM), introduced by Hood (1991), is a modern management approach that emerged in Europe in the early 1990s as a reaction to traditional public administration, which is considered inefficient, unproductive, and less innovative (Hood, 1991; Hughess, 1994). The focus of NPM's attention is on the implementation of decentralization, devolution, and modernization of public services (Drechsler, 2005). In current government agencies, the need for changes in public sector management is the demands of the wider community who want the public sector to produce quality products by applying the concept of general management oriented to public services. Therefore, a new idea is needed, namely New Public Management (NPM) (Hughes, 1998; Hodgson et al., 2007). According to Indrawati (2016), New Public Management (NPM) is an appropriate concept to apply, because it focuses on performance-oriented public sector management (public services), bureaucratization, results-based accountability, solving public bureaucracy into work units, pruning costs and efficiency, and the freedom of managers to manage organizations in fair competition and better direction. To get good results, the leaders of government agencies must be optimal in applying the concept so that it can improve the performance of public services (Hyndman \& Liguori, 2016). The development and implementation of NPM are not immune to several problems, which at least have occurred in various government agencies. Pressure on public sector organizations, especially central and regional government organizations and state-owned companies, to improve their performance has led to the development of a system of public

* Corresponding author.

E-mail address: hendrawati@ipdn.ac.id (H. Hamid)

(C) 2020 by the authors; licensee Growing Science, Canada doi: $10.5267 /$ j.msl.2019.12.028 
sector organizations performance-based management (Mahmudi, 2015). On the other hand, bureaucracy becomes an obstacle in service to the community, which then gives birth to a negative image of administration, including low productivity, poor public services provided, low responsiveness and responsibility, and little bureaucratic accountability.

This research was adopted and developed from several previous scientific research journals that are considered relevant to the predictors of NPM and the performance of government employees. Intelligence is an essential factor in improving the performance of government employees, and several studies have examined this. Priyono (2015) investigated and tested the effect of intelligence on the performance of Civil Servants in East Java, the results of the analysis found that intelligence has a significant impact on performance. Furthermore, Indrawati's study (2015) examines the role of leadership style in the implementation of NPM in improving managerial performance of the public sector in Indonesia. The results show that NPM influences the managerial performance of the public sector, but leadership style does not affect the relationship between NPM and managerial performance of the public sector. Furthermore, Wardhani and Riharjo (2015) also studied how the influence of the application of NPM towards improving organizational performance in Indonesia. The concept of NPM used in this study is represented into four variables, namely clear and measurable goals, decentralization, incentives, and performance measurement systems. The results showed that clear and measurable goal variables, decentralization, and incentives did not affect improving organizational performance. Consequently, the performance measurement system variables affect the increase in organizational performance. The NPM study was also examined by Muñiz et al. (2013), who studied city leadership and NPM throughout the national analysis. The research findings show that NPM and leadership affect the performance of public sector officers. Furthermore, the Pavlov and Katsamunska (2014) investigated the relationship of leadership and NPM in the central government in Bulgaria, where NPM and leadership did not affect the performance of public sector managers.

Specific studies on NPM in Indonesia have been elaborated in Pratama and Kalalinggi research (2019), finding that NPM is applied not only in countries with high levels of prosperity but also used in countries with standards similar to conditions in Indonesia. Apart from deficiencies in the implementation of regional autonomy, the application of NPM in the management of local government in Indonesia has a positive impact on several things, the accountability performance of government institutions and a more trapped moratorium and early retirement policies for civil servants who do not qualify as an effort to improve efficiency and the productivity performance of local governments, which in turn will improve the quality of public services. Referring to the flow of the previous research arguments above, several predictors of NPM and performance can be drawn, namely intelligence, leadership, quality of human resources. The construct is one of the novelties of this research, considering that performance testing through NPM is still very rarely found in Indonesia. Some previous studies also still show inconsistencies in results (significance), so that requires further confirmation to get a comprehensive understanding. To test the data, analysis of variance-based Structural Equation Modeling (SEM) or Partial Least Square (PLS) was applied (Ashoer, 2019), where previous studies only used regression or descriptive analysis. Another thing that distinguishes this research is the addition of culture-based indicators of local wisdom in the research object, namely South Sulawesi, Siri '. Siri 'culture, is a principle of Bugis-Makassar culture (local wisdom) that teaches shame when a leader does not carry out or ignore a good in an organization. This addition aims to describe respondents as they are. This study also focuses on the role of NPM mediators in relations between constructs, and it is crucial to know to be able to describe the extent to which predictors influence performance in this study.

\section{Theoretical review}

\subsection{New Public Management (NPM)}

NPM is a paradigm that uses a theoretical basis that is rooted in the economy by relying on rationality known as "economic man", public interests are aggregated by individual interests, service users are seen more as customers as developed by the sector private, the role of government is only as a catalyst that supports the functioning of market mechanisms, creating mechanisms and incentive structures to realize the success of its policies, accountability mechanisms on market mechanisms (Denhardt and Denhardt, 2003). NPM requires the organization to have clear objectives, and there are setting performance targets. These performance targets are obligations imposed on managers or personnel to be achieved. Setting performance targets must be linked to performance standards and performance measures. The setting of performance standards provides the best value and practice, while performance measures determine to assess the success or failure of achieving performance targets and organizational goals (Lynn, 2006).

\subsection{Intelligence}

Intelligence is the ability to understand the world, reason, and use resources effectively when faced with challenges. Besides, intelligence can also be interpreted as a personal ability to understand, innovate, and provide solutions to various situations. The types of intelligence that are generally understood today consist of; intellectual intelligence or Intelligence Quotient (IQ), emotional intelligence or Emotional Quotient (EQ), and spiritual intelligence or Spiritual Quotient (SQ) (Luthans, 2006).According to Hawari (2006), a leader to be able to carry out his leadership properly should have quality HR criteria with four 
intelligences including, IQ (Intelligent Quotient), EQ (Emotional Quotient), SQ (Spiritual Quotient), and CQ (Creativity Quotient), the four criteria are integrated and form an inseparable unit. Of the four intelligences, the SQ element becomes very important because a leader who has a high SQ will make his existence beneficial to others (followers and people), not vice versa utilizing others.

\subsection{Leadership}

Leadership concerns the interaction of leaders with other individuals (Wong \& Law, 2002). Once social interaction is involved, emotional awareness and emotional regulation become essential factors that influence the quality of communication (Pastor, 2014). Leadership is the ability of leaders to carry out leadership roles, namely the ability to influence other people or groups of followers to achieve organizational goals (Kouzes \& Posner, 1987). Behn (in Islam, 2010) identified eight responsibilities of public sector leadership: First, trying to achieve the public interest. Secondly, identify successes by benchmarking. Third, develop strategies to achieve success. Fourth, analyze the possible consequences of decisions. Fifth, emphasize the existence of precise details of the implementation. Sixth, to achieve broader goals of influence by motivating members and stakeholders to create a positive environment with consensus. Seventh, recognize and utilize their luck and, when they are unlucky, stay focused on their goals, public, and groping their way in that direction. Eighth, make the organization better than that.

\subsection{Human Resource Quality (HR Quality) Quality}

Human resources are human resources who have expertise, professionalism, and can independently compete healthily in the world of work (Kurniawaty, 2019). Bureaucrats are officials who act bureaucratically. Upholding values systematically. Bureaucrats defend innovation at work. Progress is not something that is targeted because it is too racing against existing rules. Apparatus, as the executor of the bureaucracy, often forgets the government's goal as a public servant. The device prioritizes the form of organization and the ways that are often implemented. Community demands for various service sectors not only cover the number of services but also the quality of services must be better. The importance of professional bureaucrats, both domiciled as leaders and as staff or followers, who can provide full services, both in quantity and quality (Gutiérrez-Gutiérrez, 2018).

\section{Conceptual review and hypotheses}

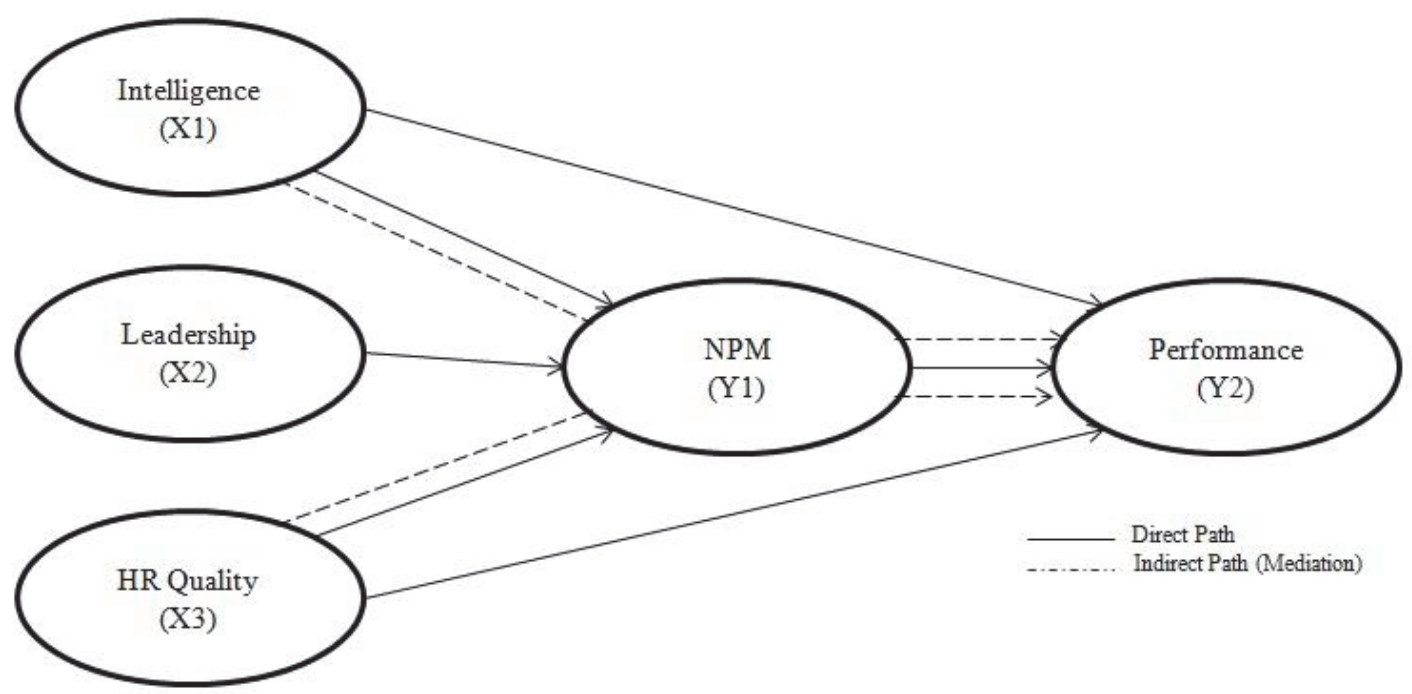

Fig. 1. Proposed Conceptual Review

Referring to the formulation of the problem and previous research that has been presented before, the proposed hypothesis is as follows:

H1: Intelligence has a positive and significant effect on NPM.

H2: Leadership has a positive and significant effect on NPM.

H3: HR quality has a positive and significant effect on NPM.

H4: NPM has a positive and significant effect on performance. 
H5: Intelligence has a positive and significant effect on performance.

H6: Leadership has a positive and significant effect on performance.

H7: HR quality has a positive and significant effect on performance.

H8: NPM significantly mediates relationship between iintelligence and performance.

H9: NPM significantly mediates relationship between leadership and performance.

H10: NPM significantly mediates relationship between HR quality and performance.

\subsection{Method}

This research used a descriptive approach and a confirmatory approach. The population in this study were officials and leaders in the city of Makassar. Thus, the number of structural officials in Makassar City totaling 1,668 officials. The research uses the Slovin formula because, in sampling, the numbers must be representative so that the results of the study can be generalized, and the calculations do not require a table of the number of samples but can be done with formulas and simple calculations (Zikmund et al., 2013). Based on the calculation above, the sample of respondents in this study was adjusted to 100 people or around $12 \%$ of the total structural officials in the Makassar city government to facilitate data processing and for better testing results. Samples were selected based on purposive sampling technique. The location of this research is in several Regional Government Organizations (OPD) in Makassar City. This study takes the object of the city government agencies that provide services to the public, both licensing and non-licensing. The time used to conduct this research is estimated to be \pm 3 (three) months, namely August to October 2019. Data collection techniques (instruments) used were a questionnaire, interview, and document search. The data analysis method used in this study is data analysis using SmartPLS software. PLS (Partial Least Square) is a variance-based structural equation analysis (SEM) that can simultaneously test measurement models as well as structural model testing (Mashur et al., 2019). The measurement model is used to test the validity and reliability, while the structural model is used to prove causality (hypothesis testing with predictive models). Furthermore, Rigdon et al. (2017) explained that PLS is an analysis method that is soft modeling because it does not assume the data must be with a specific scale measurement, which means the number of samples can be small (under 100 samples). The fundamental difference between PLS, which is an SEM-based variant with LISREL or AMOS is covariant based. Compared with covariance-based SEM (represented by AMOS, LISREL and EQS software) based components are PLS able to avoid the two major problems faced by covariance-based SEM, namely inadmissible solution and indeterminacy factor (Hair et al., 2017).

\subsection{Results}

\subsubsection{Measurement Model (Outer Model)}

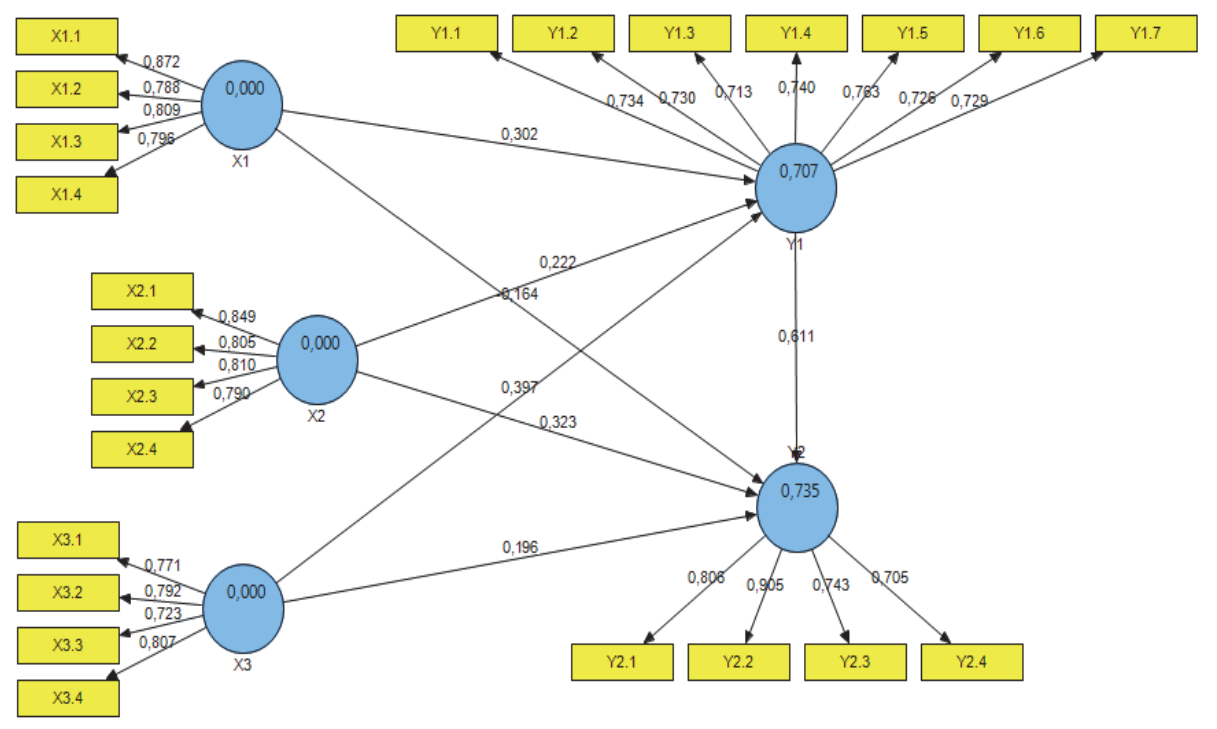

Fig. 2. SEM-PLS Measurement Model (Outer Model)

The outer model analysis uses three measurement components, namely, discriminant validity, convergent validity, and composite reliability. Discriminant validity calculation is measured by cross loading with the criterion that if the loading value of an item in a corresponding variable is higher than the value of loading an item in another variable, then the item is declared valid in measuring the corresponding variable. Based on cross loading measurements (Table 1), all items that measure the 
variables of intelligence, leadership, HR quality, NPM, and performance produce a loading value that are greater than the value of loading on other variables. Thus, it can be stated that each item can measure latent variables that correspond to these items. The next test evaluates the construct validity value by calculating convergent validity. The convergent validity criterion is identified by loading factors. An instrument is valid if it has a loading factor above 0.7. Based on the test results (Table 2), all items are greater than 0.7 . Thus, the items are declared valid to measure their respective constructs.

Table 1

Discriminant Validity Measurement

\begin{tabular}{|c|c|c|c|c|c|}
\hline & $\mathrm{X} 1$ & $\mathrm{X} 2$ & $\mathrm{X} 3$ & Y1 & Y2 \\
\hline X1.1 & 0.872 & 0.668 & 0.682 & 0.724 & 0.541 \\
\hline $\mathrm{X} 1.2$ & 0.788 & 0.541 & 0.634 & 0.463 & 0.492 \\
\hline X1.3 & 0.809 & 0.509 & 0.590 & 0.538 & 0.420 \\
\hline X1.4 & 0.796 & 0.656 & 0.550 & 0.711 & 0.603 \\
\hline $\mathrm{X} 2.1$ & 0.592 & 0.849 & 0.721 & 0.721 & 0.712 \\
\hline $\mathrm{X} 2.2$ & 0.584 & 0.805 & 0.543 & 0.596 & 0.577 \\
\hline $\mathrm{X} 2.3$ & 0.581 & 0.810 & 0.547 & 0.503 & 0.500 \\
\hline X2.4 & 0.650 & 0.790 & 0.539 & 0.539 & 0.608 \\
\hline X3.1 & 0.656 & 0.555 & 0.771 & 0.542 & 0.521 \\
\hline X3.2 & 0.633 & 0.643 & 0.792 & 0.610 & 0.549 \\
\hline X3.3 & 0.504 & 0.449 & 0.723 & 0.609 & 0.407 \\
\hline X3.4 & 0.540 & 0.604 & 0.807 & 0.665 & 0.719 \\
\hline Y1.1 & 0.664 & 0.461 & 0.631 & 0.735 & 0.487 \\
\hline Y1.2 & 0.637 & 0.428 & 0.542 & 0.730 & 0.501 \\
\hline Y 1.3 & 0.511 & 0.491 & 0.578 & 0.713 & 0.532 \\
\hline Y1.4 & 0.529 & 0.649 & 0.585 & 0.740 & 0.661 \\
\hline Y1.5 & 0.520 & 0.565 & 0.593 & 0.763 & 0.665 \\
\hline Y1.6 & 0.461 & 0.523 & 0.481 & 0.726 & 0.646 \\
\hline Y1.7 & 0.470 & 0.501 & 0.477 & 0.729 & 0.571 \\
\hline Y2.1 & 0.461 & 0.607 & 0.547 & 0.662 & 0.806 \\
\hline Y 2.2 & 0.656 & 0.691 & 0.731 & 0.769 & 0.905 \\
\hline Y2.3 & 0.495 & 0.532 & 0.487 & 0.591 & 0.743 \\
\hline Y2.4 & 0.388 & 0.522 & 0.502 & 0.577 & 0.705 \\
\hline
\end{tabular}

* X1: Intelligence; X2: Leadership; X3: HR Quality, Y1: NPM; Y2: Performance

* Indicators on a construct that all its higher cross loading with other constructs

Table 2

Convergent Validity and Reliability Measurement

\begin{tabular}{|c|c|c|c|c|c|}
\hline Construct & Items & Loadings & $\mathrm{CR}$ & $\mathrm{CA}$ & AVE \\
\hline \multirow[t]{5}{*}{ Intelligence (X1) } & & & 0.889 & 0.836 & 0.667 \\
\hline & $\mathrm{X} 1.1$ & 0.872 & & & \\
\hline & $\mathrm{X} 1.2$ & 0.788 & & & \\
\hline & $\mathrm{X} 1.3$ & 0.809 & & & \\
\hline & $\mathrm{X} 1.4$ & 0.796 & & & \\
\hline \multirow[t]{5}{*}{ Leadership (X2) } & & & 0.887 & 0.831 & 0.662 \\
\hline & $\mathrm{X} 2.1$ & 0.844 & & & \\
\hline & $\mathrm{X} 2.2$ & 0.785 & & & \\
\hline & $\mathrm{X} 2.3$ & 0.841 & & & \\
\hline & $\mathrm{X} 2.4$ & 0.806 & & & \\
\hline \multirow[t]{5}{*}{ HR Quality (X3) } & & & 0.856 & 0.778 & 0.599 \\
\hline & $\mathrm{X} 3.1$ & 0.771 & & & \\
\hline & X3.2 & 0.792 & & & \\
\hline & X 3.3 & 0.723 & & & \\
\hline & $\mathrm{X} 3.4$ & 0.807 & & & \\
\hline \multirow[t]{8}{*}{ NPM (Y1) } & & & 0.856 & 0.778 & 0.501 \\
\hline & Y1.1 & 0.735 & & & \\
\hline & Y1.2 & 0.730 & & & \\
\hline & Y1.3 & 0.713 & & & \\
\hline & Y1.4 & 0.740 & & & \\
\hline & Y1.5 & 0.763 & & & \\
\hline & Y1.6 & 0.726 & & & \\
\hline & Y1.7 & 0.729 & & & \\
\hline \multirow[t]{5}{*}{ Performance (Y2) } & & & 0.870 & 0.800 & 0.629 \\
\hline & Y2.1 & 0.806 & & & \\
\hline & Y2.2 & 0.905 & & & \\
\hline & Y 2.3 & 0.743 & & & \\
\hline & $\mathrm{Y} 2.4$ & 0.705 & & & \\
\hline
\end{tabular}

*CR: Composite Reliability; CA: Cronbach Alpha; AVE: Average Variance Extracted

Discriminant reliability (AVE), Cronbach alpha (CA), and composite reliability (CR) were measured. The criteria stated that if discriminant reliability (AVE) is greater than 0.5 , Cronbach alpha is greater than 0.6 and composite reliability is greater 
than 0.7, the construct is declared reliable. The reliability test shows (Table 2) that all latent constructs have AVE values greater than 0.5 , CA values greater than 0.6 , and $\mathrm{CR}$ values greater than 0.7 . Hence, based on reliability criteria, all items can be declared reliable in measuring latent variables.

\subsubsection{Structural Model (Inner Model)}

Testing the inner model in SEM-PLS refers to the value of Goodness of Fit, namely the ability of endogenous variables to explain the diversity of exogenous variables, or in other words, to find out the magnitude of the contribution of exogenous variables to endogenous variables. Goodness of fit Model in PLS analysis is performed using Q-Square predictive relevance $\left(\mathrm{Q}^{2}\right)$. The calculations show that $\mathrm{Q}^{2}$ is worth 0.923 or $92.3 \%$, meaning that the contribution of intelligence, leadership, quality of human resources, and overall NPM to variable performance of $92.3 \%$, while the remaining $7.7 \%$ is the contribution of other variables that are not addressed in this study. The next test is the hypothesis test and determines the significance of the influence of exogenous variables on endogenous variables, both directly and indirectly path. SEM-PLS explains that the hypothesis significance measure by comparing T-table and T-statistic values. If the T-statistic is higher than the T-table value, then the hypothesis is accepted. The 95 percent confidence level (or $5 \%$; $<0.05$ ) for the two-tailed hypothesis is $>1.96$. The following describes the hypothesis testing in detail.

Table 3

Summary of Hypothesis Assessment

\begin{tabular}{|c|c|c|c|c|c|c|}
\hline Нyp. & Direct Effect & Coefficient & S.E. & T-Stats & P Value & Result \\
\hline H1 & Intelligence $\rightarrow$ NPM & 0,302 & 0,080 & 3,764 & 0,004 & Supported \\
\hline H2 & Leadership $\rightarrow$ NPM & 0,223 & 0,070 & 3,200 & 0,022 & Supported \\
\hline H3 & HR Quality $\rightarrow$ NPM & 0,398 & 0,075 & 5,271 & 0,000 & Supported \\
\hline H4 & NPM $\rightarrow$ Performance & 0,611 & 0,091 & 6,686 & 0,000 & Supported \\
\hline H5 & Intelligence $\rightarrow$ Performance & 0,164 & 0,103 & 1,593 & 0,145 & Rejected \\
\hline H6 & Leadership $\rightarrow$ Performance & 0,323 & 0,091 & 3,544 & 0,009 & Supported \\
\hline H7 & HR Quality $\rightarrow$ Performance & 0,196 & 0,076 & 2,579 & 0,038 & Supported \\
\hline Нyp. & Indirect Effect (Mediation) & Coefficient & S.E. & T-Stats & $\mathbf{P}$ & Result \\
\hline H8 & Intelligence $\rightarrow$ NPM $\rightarrow$ Performance & 0,221 & 0,105 & 2,104 & Sig & Supported \\
\hline H9 & Leadership $\rightarrow$ NPM $\rightarrow$ Performance & 0,459 & 0,091 & 5,021 & Sig & Supported \\
\hline H10 & HR Quality $\rightarrow$ NPM $\rightarrow$ Performance & 0,373 & 0,093 & 4,014 & Sig & Supported \\
\hline
\end{tabular}

The test results show that the construct of intelligence, leadership, and HR quality have positive and significant effects on NPM with path coefficients of $0.302,0.223$, and 0.398 , respectively. Further results show that the latent variables of leadership (0.323), HR quality (0.196), and NPM (0.611) have positive and significant effects on performance. Still, the intelligence variable $(0,164)$ has no significant impact on performance (Table 3). Thus, it can be concluded that H1, H2, H3, H4, H6, and $\mathrm{H} 7$ were accepted while $\mathrm{H} 4$ was rejected. The indirect test results show that the mediation test of the NPM variable as a mediator variable on the effect of intelligence, leadership, and HR quality on performance is having a significant impact. All mediation coefficient paths show a significance value of $\mathrm{p}$-value $<0.05$, and T-statistic $>1.96$. That is, the NPM variable can mediate the indirect effect of intelligence, leadership, and HR quality variables on the performance of government employees. Thus, it can be stated that H8, H9, H10 are accepted.

\section{Discussion}

The study has tried to answer the relationship between the performance of government employees in the city of Makassar, Indonesia, and identified the direct and indirect effects of performance on intelligence, leadership, quality of human resources, and the New Public Management (NPM). The discussion focused on decisions resulting from testing hypotheses to answer the research problem formulation. The results have confirmed or rejected some of the previous research findings referred to study, and their justification was then narrated. The results of the antecedents of intelligence indicate that there was a positive and significant influence on NPM. This means that government employees who are domiciled in the Makassar City government were considered to maximize four intelligences (IQ, EQ, CQ and SQ) so that they were able to carry out a new concept of NPM in government, namely a new, modern, flexible management system and professional in providing public services. Descriptive statistical results have shown that the indicator that had the highest average was intellectual intelligence (IQ), where respondents in this case were structural officials Level II, III and IV agree that intelligence possessed could affect themselves at work, which then impacts on achieving success in an organization. Even so, intelligence does not significantly influence the performance of Makassar city government employees. That is, respondents consider that the intelligence currently possessed has not had a direct impact on the performance of government employees. One intelligence that is considered not maximal is spiritual intelligence, where respondents still do not fully understand their existence can be useful for others (followers and people), not the other way around utilizing others. Although academically, their IQ levels are qualified, minimal spiritual aspects cause violations of behavioral, ethical, and moral values. The second predictor is the leadership variable. The results have shown that leadership directly had a positive and significant influence on NPM and the performance of government employees in Makassar City. Leadership will actively support the application of NPM in the delivery of quality 
public services, and can then improve the performance of government employees. "Give an example" is the first indicator that reflects the leadership variable, when structural officials exemplify the correct ways of carrying out their duties and responsibilities according to their duties and authorities, it is also well followed by their subordinates in carrying out work. Kouzes and Posner (2004) restated that to determine how serious leaders are, evaluating actions is more vital than assessing their words. Furthermore, the construct of HR quality has a positive and significant effect on NPM and the performance of Makassar City government employees. This means that good HR quality contributes significantly to the application of the NPM concept and performance improvement. Experience is one indicator that reflects the variable quality of HR. Structural officials who have work experience with a positive trade record will be superior in facing the challenges of system changes in governance, especially in abandoning old patterns. These qualities are needed in realizing bureaucratic reform in public services in Makassar City. Mediation testing shows that the NPM variable mediates the effect of intelligence, leadership and HR quality on the performance of government employees in the city of Makassar, Indonesia. Employees who have the strong leadership capacity and quality can drive performance improvements through the implementation of NPMs that are oriented towards efficiency and effectiveness. Categorically, this study also proves the role of NPM in mediating the insignificant influence between intelligence and performance. Several indicators were considered respondents NPM helps increase performance include budget discipline, running performance standards, professional management, indicator reward accountable and integrity, and indicators of the division of authority and responsibility. The implementation of NPM requires its users to always look for innovations in improving performance to achieve organizational goals.

\section{Conclusion and future research}

Test results have shown that the construct of intelligence, leadership, and HR quality has a positive and significant effect on NPM. The results showed that the latent variables of leadership, HR quality, and NPM had a positive and significant impact on performance. Still, the intelligence variable was found to have no significant effect on performance. Indirect test results have shown that the mediation test of NPM variables as a mediator variable on the influence of intelligence, leadership, and HR quality on performance had a significant effect. That is, the NPM variable can mediate the indirect effect of the variables of intelligence, leadership, and HR quality on the performance of government employees. The results support or reject some of the previous studies used as a reference in this study. Theoretical contributions are expected to have an impact on the development of human resource management theories, especially those related to performance, leadership and quality of HR.

This study uses only three independent variables and is not accompanied by moderating variables, for example, accompanied by training variables, work knowledge, or work experience. This will result in a lack of control over the influence of the three variables on employee performance if not accompanied by a moderator variable. The results of this study cannot be generalized to other cases outside the research object so that subsequent research can expand the research object. This study only uses questionnaires as a data collection tool and is not accompanied by other data collection methods that can support research, such as interviews. This research also only uses cross-section data, where has limitations in explaining the stability of the relationships between variables involved in a study from time to time.

\section{References}

Ashoer, M., Syahnur, H., \& Murdifin, I. (2019). Bagaimana Gaya Hidup mempengaruhi Keputusan Pembelian Tiket Online. Jurnal Ilmiah Manajemen dan Bisnis, 20(1), 52-65.

Denhardt, J. V., and Denhardt. R. B. (2003). The New Public Service: Serving Not Steering, Armonk, NY: ME Sharpe.

Drechsler, W. (2005). The Rise and Demise of the New Public Management. Post Autistic Economic Review, 33, 17-28.

Gutierrez-Gutierrez, L. J., Barrales-Molina, V., \& Kaynak, H. (2018). The role of human resource-related quality management practices in new product development: A dynamic capability perspective. International Journal of Operations \& Production Management, 38(1), 43-66.

Hair, J. F., Hult, G. T. M., Ringle, C. M., and Sarstedt, M. (2017). A Primer on Partial Least Squares Structural Equation Modeling (PLS-SEM) (2nd Edition). Thousand Oaks: Sage Publications, Inc.

Hawari, D. (2006), IQ, EQ, CQ and SQ: Human Resources Quality Criteria. New Style: Jakarta

Hodgson, L., Farrell, C. M., \& Connolly, M. (2007). Improving UK public services: A review of the evidence. Public Administration, 85(2), 355-382.

Hood, C. (1991). A public management for all seasons?. Public Administration, 69(1), 3-19.

Hughess, O. (1994). Public Management and Administration, London: St Martin's Press.

Hyndman, N., \& Liguori, M. (2016). Public sector reforms: changing contours on an NPM landscape. Financial Accountability \& Management, 32(1), 5-32.

Indrawati, L. (2016). Peran Gaya Kepemimpinan Terhadap Implementasi New Public Management Dalam Peningkatan Kinerja Manajerial SektorPublik.

Kouzes, J.M., \& Posner, B.Z. (1987). Leadership the Challenge. Terjemahan: Refyani Sjahrial. Jakarta. Erlangga.

Kurniawaty, K., Ramly, M., \& Ramlawati, R. (2019). The effect of work environment, stress, and job satisfaction on employee turnover intention. Management Science Letters, 9(6), 877-886.

Lynn, L. E. (2006). Public Management: Old and New. Routledge: New York and London. 
Luthans, F. (2006). Organizational Behavior. Publisher Andi: Jakarta.

Mashur, R., Gunawan, H., Ashoer, M., and Fitriany. (2019). Moving from traditional to society 5.0: Case study by online transportation business. Journal of Distribution Science, 17(9), 93-102.

Mahmudi (2015). Manajemen Kinerja Sektor Publik. UPP STIM YKPN: Yogyakarta.

Muñiz, J., Elosua, P., \& Hambleton, R. K. (2013). Directrices para la traducción y adaptación de los tests: segunda edición. Psicothema, 25(2), 151-157.

Pastor, I. (2014). Leadership and emotional intelligence: the effect on performance and attitude. Procedia Economics and Finance, 15, 985-992.

Pavlov, P., \& Katsamunska, P. (2004, May). The relationship of leadership and new public management in central government: Bulgarian specifics. In 12th Conference of the Network of Institutes and Schools of Public Administration in Central and Eastern Europe.

Pratama, P. Y., \& Kalalinggi, R. (2019). Application of new public management (NPM) in Indonesia in the field of transportation (Case In Bandar Lampung). Journal of Governance and Public Policy, 6(2), 126-147.

Priyono. (2015). Effect of Intelectual Intelligence, Emotional Intelligence and Spiritual Intelligence to Performance Civil Servants Language Center East Java. Jurnal International, 13(9).

Rigdon, E. E., Sarstedt, M., \& Ringle, C. M. (2017). On comparing results from CB-SEM and PLS-SEM: Five perspectives and five recommendations. Marketing ZFP, 39(3), 4-16.

Wardhani, P. A., and Riharjo, I. B. (2015). Pengaruh Penerapan Konsep NPM terhadap Peningkatan Kinerja Organisasi. Jurnal Ilmu \& Riset Akuntansi, 4(7).

Wong, C. S., \& Law, K. S. (2002). The effects of leader and follower emotional intelligence on performance and attitude: An exploratory study. The Leadership Quarterly, 13(3), 243-274.

Zikmund, W. (2013). Business Research Methods (9th Ed.). Mason: OH: South-Western College Publishing.

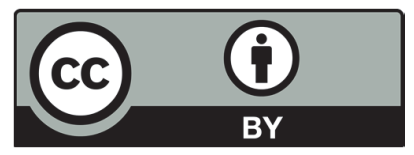

(C) 2020 by the authors; licensee Growing Science, Canada. This is an open access article distributed under the terms and conditions of the Creative Commons Attribution (CC-BY) license (http://creativecommons.org/licenses/by/4.0/). 